\title{
Tsangaya System of Education and its Positive Effects on Almajiri and Society in Potiskum, Yobe State Nigeria
}

\author{
Ibrahim Dahiru Idriss* \& Norhayati Haji Hamzah"*
}

\begin{abstract}
Tsangaya System of Education, generally called Makarantan Allo or traditional Qur'anic school has been in existence for decades, its history can be traced back to the early days of the coming of Islam to Nigeria. It has been a source of moral and scholastic training of the Muslim dominated societies in the northern part of Nigeria. The system which provides essentially, basic Qur'anic education to the Almajiri (students) has contributed tremendously in promoting Qur'anic education, inculcating selfdiscipline, spiritual growth of Muslim individuals and the communities. Therefore, this article examines the positive effects of Tsangaya System of Education on the Almajiri in Potiskum Yobe State, Nigeria. The study employed a qualitative approach that entails the techniques of documentation and interviews in collecting data while thematic analysis was utilized for data analysis. The findings revealed that Tsangaya System of Education in Potiskum area of Yobe State has positive effects on the Almajiri in the area such as mastering the recitation, memorization and writing of the glorious Qur'an as well as inculcating good behavioural modes.
\end{abstract}

Keywords: Islamic education, Tsangaya System of Education, Positive Effects, Almajiri, Potiskum Yobe State

\section{Introduction}

Tsangaya refers to the informal school or place where teaching and learning of the glorious Qur'an and other Islamic sciences are taken place. The early Tsangaya schools were day institutions, children are attending from the comfort of their homes living with their families receiving proper guidance, teaching and learning. ${ }^{1}$ The word Tsangaya is derived from the Sangaya in Kanuri, which means educational institution. ${ }^{2}$ Consequently, Sangaya is the real name while Tsangaya is Hausa alteration of the word. On the other hand, the term Tsangaya School is known as Makarantar Allo derives its name from what is largely visible in the school that is the wooden slate Allo in Hausa language. Apart from the general name, Tsangaya has other names such as Makarantar Muhammadiyya, Makarantar al-Qur'ani, Makarantar Toka, etc. ${ }^{3}$ Meanwhile the word Almajirit is derived from the Arabic word Almuhajirun which means migrants. It refers to the students who enrol into the traditional method of acquiring and memorizing the glorious Qur' an in Hausa land, it is also referred to a particular place where children at their tender ages are sent out by their parents to other villages, towns and cities for acquiring the knowledge of the glorious Qur'an under the care of a knowledgeable Islamic scholar Alaramma, Mallam or Goni.

Tsangaya System of Education is regarded as one of the main Islamic systems of education which has been developed in Nigeria. It is believed that the Tsangaya System has a long history of existence. Its origin can be traced to the old Timbuktu scholastic culture ${ }^{5}$ where Timbuktu, located in the Western Africa in the Republic of Mali was the centre of Islamic education and Islamic scholarship. Many books were written and copied in Timbuktu staring from the 14th century. Besides that, University of

\footnotetext{
* Ibrahim Dahiru Idriss, Lecturer II, Department of Primary Education, Federal College of Education (Technical), Potiskum Yobe State, Nigeria. Currently he is a Ph.D candidate at International Islamic University Malaysia. Email: ibrahimdahiruidriss@gmail.com.

${ }^{* *}$ Norhayati Haji Hamzah (Ph.D), (corresponding author). Senior Lecturer, Department of Islamic History and Civilization, University of Malaya, Kuala Lumpur, Malaysia. Email: yati611@um.edu.my.

${ }^{1}$ Babajo, H. H., Jamaluddin, Z., \& Hamid, S. A. (2017), "The Challenges of Tsangaya Quranic Schools in Contemporary Societies: A Study of Kano State Nigeria," Asian Journal of Multidisciplinary Studies, Vol. 5, No. 6, pp. 243-250.

${ }^{2}$ Bano, M., Antonisis, M. \& Ross, J. (2011), Islamiyya, Qur'anic and Tsangaya Education Institutions Census in Kano State (Final Draft Report), Kano, Nigeria: Education Sector Support Programme, Kano University.

${ }^{3}$ Babajo, H. H., Jamaluddin, Z., \& Hamid, S. A. (2017), "The Challenges of Tsangaya Quranic schools in Contemporary Societies: A Study of Kano State Nigeria," pp. 243-250.

${ }^{4}$ Almajirai serves as the plural of Almajiri. Refer to Bambale, K. (2003), "The need for the reform of Almajiri System to Education for attainment of the Nigeria Vision 2020," Farfaru Journal of Multi-Disciplinary Studies (Special Conference Edition), Vol. 3, pp. 519-524.

${ }^{5}$ Shuriye, A. O., \& Ibrahim, D. S. (2013), "Timbuktu Civilization and Its Significance in Islamic History," Mediterranean Journal of Social Sciences, Vol. 4, No. 11, p. 696.
} 
Timbuktu was established and later became well-known throughout Islamic world. Thus, the spirit of old Timbuktu scholastic culture has later influenced the emergence of Tsangaya System of Education in northern Nigeria. The presence of the Tsangaya System of Education in Potiskum local government, Yobe State has affected the lives and the mindset of the indigenes of the area in different ways. The system has brought many remarkable scholars in the fields of Qur' an and its sciences, teaches the people acts of worship, changes the mindset of the people towards inculcating good behavioral modes and bring unity among the people. Besides that, Tsangaya System had over a long period of time graduated many Islamic scholars who later took the responsibility of teaching and spreading the religion of Islam nationwide. Although there are a lot of challenges surrounded the system, but it has recorded many successes over the period of time.

\section{Literature Review}

Prior studies have elaborated on the historical background of the Tsangaya System of Education. Babajo, et al., discuss the establishment of Tsangaya System of Education dated back to the colonial times, and explores how it has been a source of educational training and good morals to the dominated Muslims communities in northern Nigeria. ${ }^{6}$ Muhammad states that Tsangaya schools were established before the advent of the colonial masters. ${ }^{7}$ Kabir agreed that in the most part of West Africa, the Qur'anic schools had been established prior to the way the coming of the colonialist. ${ }^{8}$ In addition, Yahya exposed that, the Tsangaya schools were introduced to Kanem Borno since from the very beginning of the Islamic religion in the area, Kanem Borno gradually became the center for the Qur'anic learning and recitation more than any other town in the Hausaland and it expel in that until the present time. ${ }^{9}$ The center has produced a number of experts in the writing and recitation of the glorious Qur'an. The Emirs of Kanem Borno at that time generously financed and supported the Qur'anic schools and their teachers. Furthermore, the influences of the center have spread to the neighboring state in the Hausaland. ${ }^{10}$ Differed from the above opinions, Ayuba argues that the Tsangaya System of Education originated from the prophetic era. ${ }^{11}$ Similarly, Adamu also traces the historical background of the establishment of Tsangaya System of Education by saying that the practice has stated as a result of the Prophet's da'wah. ${ }^{12}$ He further affirmed that the prophet (peace be upon him) taught his companions the glorious Qur'an in his Masjid (Mosque) and that was the first Qur'anic school and Islamic center for the Muslims where all Islamic related issue were observed. ${ }^{13}$ It was reported that the Prophet have advised the Muslim to travel even up to China in searching for knowledge. ${ }^{14}$

Moreover, Adamu examines that Tsangaya System of Education in northern part of Nigeria has divided into two; an elementary part which is called Kutb, and a more advanced part called Madrasa. ${ }^{15}$ Furthermore, he states that Tsangaya System of Education is a center for knowledge acquisition whereby both the teachers and the students travel wide out of their towns of origin and most cases stay there for a long period of time for the purpose of recitation and memorization of the glorious Qur'an. ${ }^{16}$ Usman reveals that with respect to the Tsangaya schools, the curriculum is extremely restricted to the recitation and memorization of the glorious Qur'an. ${ }^{17}$ Odumusu mentions that the basic stages was intended for learning the Qur'anic alphabets, reading and writing, while the higher stage is the stage of memorization of the whole Qur'an as well as ability to inscribe it from the heart. ${ }^{18}$ Meanwhile, Babajo

\footnotetext{
${ }^{6}$ Babajo, H. H., Jamaluddin, Z., \& Hamid, S. A. (2017), "The Challenges of Tsangaya Quranic Schools in Contemporary Societies: A Study of Kano State Nigeria," pp. 243-250.

${ }^{7}$ Muhammad, R., Yusuf, A., \& Bello, M. B. (2013), "Teachers and Parents' Assessment of the Inclusive Education of the Almajiri and Education for All in Nigeria," Journal of Resourcefulness and Distinction, Vol. 6, No. 1, pp. 1-11.

${ }^{8}$ Kabir, I. (2012), "The Almajiri Phenomenon," Gamji online, http://www.gamji.com [retrieved 26 July 2020].

${ }^{9}$ Yahya A. (2018), “Tsangaya: The Traditional Islamic Education System in Hausaland,” Jurnal Pendidikan Islam,Vol. 4, Bo. 1, pp. 1-14.

${ }^{10}$ Yahya (2018), "Tsangaya: The Traditional Islamic Education System in Hausaland," pp. 1-14.

${ }^{11}$ Ayuba, S. D. U. (2009), "Begging among Almajiri Qur'anic boarding school children of Almajici system of education in Sokoto metropolis," Unpublished M. Ed. Dissertation, Department of Education, UDU, Sokoto.

12 Adamu, A. U. (2010), "Islamic Education in African Countries - The Evolution of Non-Formal Al-Muhajirun Education in Northern Nigeria," Discussion paper, Workshop of Islamic Education in African Countries, Istanbul, Republic of Turkey, 14-18 June 2010.

13 Adamu (2010), "Islamic Education in African Countries."

${ }^{14}$ Ayuba (2009), "Begging among Almajiri Qur'anic boarding school children of Almajici system of education in Sokoto metropolis." See also, Yusha'u, M. et al. (2013), "Problems and prospects of integrated almajiri education in northern Nigeria," Scientific Journal of Pure and Applied Sciences, Vol. 2, No. 3, pp. 125-134.

${ }_{15}$ Adamu (2010), "Islamic Education in African Countries."

${ }^{16}$ Adamu (2010), "Islamic Education in African Countries."

${ }^{17}$ Usman, T. (2018), "Qur'anic Schools in Northern Nigeria: Past Glory and Prevailing Challenges,” Dirasat Tarbawiyah, Vol. 7, pp. 1-25.

${ }^{18}$ Odumosu, O. et al. (2013), Manifestations of the Almajirai in Nigeria: Causes and Consequences, Nigerian Institute of Social and Economic Research.
} 
reported that five stages are involved in the Tsangaya Educational System which includes; Babbaqu, Farfaru, Zube, Haddatu and Satuu. ${ }^{19}$ These literatures are no doubt very much related to this study especially in term of the history of Tsangaya System of Education in Northern Nigeria, particularly Yobe State.

\section{Methodology}

The study employed a qualitative-historical approach that entails the techniques of documentation and interviews in collecting data while inductive approach of thematic analysis was utilized for data analysis. Interviews is the main method of data collection in this research using semi-structured interviews. A semi-structured interview is a type of interview in which the interviewer asks only a few predetermined questions while the rest of the questions are not planned in advance. ${ }^{20}$ Individual interviews have been chosen for this research because it will provide a valid and an effective of examining participant's experiences and perspectives as well. Specifically, the participants involved are (5) Almajiri, (5) Teachers, (3) stake holders from the government agencies, (3) parents of the Almajiri, and (3) peoples living with the Almajiri. The interview participants were coded as $A L J, A L M, G O F$, and PLA. Finally, thematic data analysis is used in analysing the data gathered from the interview.

\section{Findings and Discussion}

\section{Positive Effects of Tsangaya System of Education on Almajiri in Potiskum, Yobe State}

The establishment of the Tsangaya System of Education in Potiskum, Yobe State and the presence of the Almajiri has contributed to the development of the educational system in the area. Based on research, it cannot be denied that Tsangaya System of Education has made a significant contribution to the development of Islam in the mentioned area especially in preserving the tradition of memorizing the Qur'an among the society. In fact, the system has affected the social, moral and spiritual situations of the Potiskum and the other areas of Yobe State. Overall, the Tsangaya System of Education in Potiskum, Yobe State has affected the Almajiri in the positive ways as the following:

\section{Mastering the Recitation, Memorization and Writing of the Holy Qur'an}

The main aim of the Tsangaya System of Education is to educate the student to learn the Qur'an and to excel in the memorization of the Qur'an and learn its sciences. The methodology used by the Tsangaya schools in Potiskum in teaching and learning the Qur'an give the Almajiri the ability to differentiate, pronounce the vowels and consonants of the Arabic language which makes it easy for the Almajiri to recite the glorious Qur'an correctly as it is revealed. Individual method of learning Qur'an is employed in which students are allowed to read at their own capacity. The teacher teaches the Almajiri specific portion of the glorious Qur'an on a wooden slate and subsequently, the Almajiri recites the portion until he mastered it. Later, the Almajiri recites the portion of the Qur'an to the hearing of his teacher, and once the teacher is satisfied of the recitation, then only he will add more portions to the ones earlier learned by the student. This method is applied continuously until the Almajiri finishes the whole Qur'an. ${ }^{21}$ The above process of recitation is followed by the memorization stage. From the very beginning the Almajiri chooses the selected chapters of the glorious Qur'an that fall within his intelligence and memorization capacity. The student takes his slate for recitation with other experts in attendance, correction is made on orthography and spelling mistakes after which student then goes on to individually memorize that portion of the Qur'an he had chosen. ${ }^{22}$ Therefore, the above-mentioned method of teaching al-Qur'an makes it possible for the Almajiri to memorize the whole Qur'an and commit it into writing easily. This point is acknowledged by few respondents in the interviews who stated that:

\footnotetext{
${ }^{19}$ Babajo, H. H. (2008), “Socio-economic Menace of Almajiri Syndrome: The way out,” Journal of Religions Education, Languages and General Studies, Vol. 2, No. 1, pp. 39-45.

${ }^{20}$ Tom Pollock, The Difference Between Structured, Unstructured \& Semi-Structured Interviews, https://www.oliverparks.com/blognews/the-difference-between-structured-unstructured-amp-semi-structured-interviews [retrieved 9 October 2020].

${ }^{21}$ Shehu, S. (2006), "Improving Qur'anic (Tsangaya) education in Nigeria: Trends, issues, challenges and the way forward," Paper presented at the Workshop Organized by Borno State Agency for Mass Education, 2nd-5th May 2006.

${ }^{22}$ Shehu (2006), "Improving Qur'anic (Tsangaya) education in Nigeria."
} 
The method of teaching and learning of the glorious Qur'an in the Tsangaya schools make the Almajiri to master the Qur'an very well, as he will write the verses of the Qur'an on his slates and recite it uncountable times, this will make him to memorize the whole portion of the Qur'an and it will be difficult for him to forget it (ALM5). ${ }^{23}$

The memorization of the glorious Qur'an by the Almajiri tend to be more feasible in the Tsangaya schools, as the Almajiri has devoted all his time learning the Qur'an day and night. The Almajiri will write the portion of the Qur'an and read it until he committed it to his memory (PLA3). ${ }^{24}$

The above statements by the participants are parallel to the opinion of Yahya (2018) who exposed that the Almajiri have been trained to the extent that they can memorize and write the glorious Qur'an from the memory simultaneously. ${ }^{25}$ Therefore, the structure of the Tsangaya schools leads to the production of Almajiri with the ability not only recite the Qur'an from the memory but simultaneously write it down from the memory. ${ }^{26}$ The Qur'anic memorization and the ability to understand the meaning of the memorized words will not only enable the memorization process but also enhance its proficiency in the Arabic language. ${ }^{27}$

\section{Inculcating Good Behavioural Modes}

The establishment of Tsangaya schools in Potiskum and the teaching of the glorious Qur'an make the Almajiri learn more deeply on the tenets of Islam and subsequently commit significant efforts to put them into practice. In fact, many Almajiris that came to study in this area (Potiskum) over the years have succeeded in memorizing the Qur'an, became preachers and guide the Muslim ummah on the right path. ${ }^{28}$ The Almajiri that spends most of his precious time learning the Qur'an is tending to be a person with piety and of good behavioural modes as Islam advocates good behaviour which has been stated inside the Qur'an. Based on interviews, among the good behavioural modes that the Almajiri inculcate include respecting elders, trust, patience, grateful and obedient to Allah. These have been disclosed by some participants as below:

The Almajiri as a Tsangaya school student, would learn the good moral conducts based on the teachings of the religion of Islam. Therefore, the Tsangaya schools' system has affected the moral lives and upbringing of its students, thereby they conduct themselves very well and decently in the society (PLA3) ${ }^{29}$

Besides that, a statement by a government official during an interview declares that:

Tsangaya school has produce a generation with good moral behaviour despite the challenges facing the system. Hence to produce a student with good moral development behaviour surely is one of the significant objectives of education. Therefore, Almajiri of Tsangaya schools are spreading morality and righteousness in their behaviours, both of which came from the Islamic teaching based i.e. Tsangaya schools. In this regard, the teachers of Tsangaya schools play a very important role in nurturing and cherishing youngest people's moral behaviour, character and personality (GOF1). ${ }^{30}$

\section{Spiritual Effect of Tsangaya System of Education on Almajiri}

In Islam, the purpose of man's creation is to worship Allah and this has been stated and emphasized by Allah inside the Qur'an in sura al-Dzariyat, versus 56. As a person or individual is not able to worship his creator without knowledge. Therefore, Tsangaya schools in Potiskum were established to educate the people on the message of Allah that is the Qur'an and the teachings of Islam so as to know how to worship their Lord accordingly. Besides the basic teaching of Qur'an, the Tsangaya schools were

\footnotetext{
${ }^{23}$ ALM5, Interview conducted with Almajiris Teacher at his residence in Arikime area Potiskum on the on 12 September 2020 at 3:11 - 3:58 p.m.

${ }^{24}$ PLA3, Online Interview with a person living with the Almajiri at his shop on the 4 October 2020 between 1:21-1:48 p.m.

${ }^{25}$ Yahya (2018), "Tsangaya: The Traditional Islamic Education System in Hausaland," pp. 1-14.

${ }^{26}$ Yahya (2018), "Tsangaya: The Traditional Islamic Education System in Hausaland,” pp. 1-14.

${ }^{27}$ Eickelman, D. F (1978), "The Art of Memory: Islamic Education and Its Social Reproduction," Comparative Studies in Society and History, Vol. 20, No. 4, pp. 485-516.

${ }^{28}$ Yusha'u et al. (2013), "Problems and prospects of integrated almajiri education in northern Nigeria," pp. 125-134.

${ }^{29}$ PLA3, Online Interview with a person living with the Almajiri at his shop on the 4th October 2020 between 1:21-1:48 p.m.

${ }^{30} \mathrm{GOF} 1$, Interview conducted with government official in His office on 10th of May 2020 from 10:00 - 10:35 a.m.
} 

engaged in teaching the Almajiri the Islamic sciences such as ulum al-Qur'an, ulum al-hadith, fiqh, tajweed, nahwu balagha and adab. According to Mashema \& Kawu, the Tsangaya System has enabled the people of the area to learn the Qur'anic science and exegesis, the Islamic law, jurisprudence, the concept of worship and the concept of interpersonal relationship between man and his fellow man. ${ }^{31} \mathrm{As}$ a result, in general, the Almajiri become concern of their responsibilities to Allah and the mankind. Concerning spiritual effect of Tsangaya System of Education on Almajiri, the interview conducted with a participant indicated that: "Almajiri that graduated from the Tsangaya schools' system, memorizes the Qur'an and learn more about the religion of Islam, they have acquired the basic of the religion of Islam and they can practice their religion and other forms of worship with good knowledge, piety and sincerity" (PLA1). ${ }^{32}$

Besides that, the people living in Tsangaya schools have exhibited the good value of spirituality and societal orientation. The Tsangaya schools were considered as places where special prayers were offered by the community especially if there is any issue burdening the community. Scholars and Almajiri gathered in Tsangaya on the daily basis to offer prayers at the beginning and the ending of every school session. Meanwhile, during the weekends scholars and their students gathered and recite the glorious Qur'an and offer special prayers for the peace and development of the nation. In addition, the presence of the Tsangaya schools in the communities has contributed to the establishment of spirituality and Islamic scholarship in which it has produced many pious Muslims and scholars who dedicated themselves in teaching and spreading the religion of Islam in the area. They also serve as a revivalist that revive and salvage the society from practicing the barbaric customs such as superstition and fortune telling, to the practice of sound authentic religion of Islam. ${ }^{33}$ Based on interviews, participants reiterated that:

The graduate of the Almajiri that studied in Potiskum over the decade has contributed in the propagation and spreading the religion of Islam in the neighboring areas. The Almajiri graduates has become the spiritual leaders in their various localities and help in changing the minds of the people towards the Islamic teachings (PLA3). ${ }^{34}$

Most of the Almajiri graduates in the Tsangaya schools has now became judges in the Shari'ah courts, Imam during the Tarawih prayers on Ramadan, Imams in Juma'at Mosques and teachers in Madarasat. They help in reforming the society. ${ }^{35}$

\section{Social Effect of Tsangaya System of Education on the Society}

The establishment of Tsangaya schools in Potiskum has affected the social life and well-being of the people in the area. In other words, the social life of the people has change as the result of the Tsangaya influence and the presence of knowledgeable Tsangaya teachers and students. The presence of the Tsangaya schools in Potiskum does not only give effects to the Almajiri but also to the society in general as most of the people of the area attended the Tsangaya schools and learn much about Islam and its ethics. Consequently, some members of the society adhere strictly to the teaching of Islam, and therefore, peaceful, prosperous and sound communities were established. According to Yahya, the Muslims of the area were able to practice the Islamic ethics regarding respect to parent, guardian, and teachers because teachers (Mallam) in the system have the function of an administrator, a teacher, a guide and a counsellor, an arbiter and a treasurer. ${ }^{36}$ Responding on the positive effect of Tsangaya school in Potiskum, a participant upheld that:

With the emergence of Tsangaya schools several years ago, the town of Potiskum was able to undertake and achieve success in many facets especially, teaching how people will leave in a peaceful co-existence and prosperity atmosphere through the guidance of Qur'an and Sunnah (PLA1) ${ }^{37}$

\footnotetext{
${ }^{31}$ Mashema, B. L., \& Kawu, G. S. (2017), “The Integration of Traditional Islamic Education Schools with The Western Education Schools Model: A Case Study of AzareTsangaya Model Boarding Primary School," International Journal of Innovative and Advanced Studies, Vol. 4, No. 7, pp. 335-343

${ }^{32}$ PLA1, Online Interview with a person living with the Almajiri at his residence on the 2nd of October 2020 at 4:00-5:30 p.m.

${ }^{33}$ Van Beek, W. E. (2012), "Intensive slave raiding in the colonial interstice: Hamman Yaji and the Mandara Mountains (North Cameroon and North-Eastern Nigeria)," The Journal of African History, Vol. 53, No. 3, pp. 301-323.

${ }^{34}$ PLA3, Online Interview with a person living with the Almajiri at his shop on the 4th October 2020 between 1:21-1:48 p.m.

${ }^{35}$ PLA1, Online Interview with a person living with the Almajiri at his residence on the 2nd of October 2020 at 4:00-5:30 p.m.

${ }^{36}$ Yahya (2018), "Tsangaya: The Traditional Islamic Education System in Hausaland," pp. 1-14.

${ }^{37}$ PLA1, Online Interview with a person living with the Almajiri at his residence on the 2nd of October 2020 at 4:00-5:30 p.m.
} 
In addition, other participants mentioned the following:

The students Tsangaya system of education in Potiskum areas has affected the lives of the people living in the area as it has produced many notable scholars and Imams in the area, as a result of the Tsangaya many people in the area has become knowledgeable on the tenets of Islam (ALM5). ${ }^{38}$

The main goal of the Tsangaya schools is to train the pupils toward the reading, writing and memorisation of the Qur'an. The teachers and the Almajiri of Tsangaya school where able to associate with the people in the society as one family (PLA2). ${ }^{39}$

Moreover, the teaching and preaching activities in the Tsangaya make the neighboring people learn more about the tenets of Islam and abide by them, thereby making the society to be morally sound environment. The presence of the Tsangaya in Potiskum has affected the moral behaviors of Potiskum and its environs and this has been exposed by a respondent in an interview that:

The Tsangaya schools has been the source of moral and educational training to northern part of Nigerian whereas Muslims are the dominant. Therefore, the system has changed the lifestyle of the people particularly in Potiskum were the social vices has been reduced drastically (PLA3). ${ }^{40}$

Furthermore, one participant described the morals impacts of the Tsangaya schools on Almajiri and the people of the area of study that:

All the Tsangaya schools are being established with the determination of upgrading the good moral upbringing and reducing moral decay among the Almajiri and the society at large. Therefore, Tsangaya schools are the subordinate to parents and community as well in providing good ethics (GOF2). ${ }^{41}$

Apart from the above-mentioned points, there are also other effects from the establishment of Tsangaya System of Education on the society in Potiskum. Social and moral vices were reduced to the minimal level as a result of the activities of Tsangaya schools and the Almajiri in Potiskum area. The social menace of the society that has started from the time of the establishment of Tsangaya until present was reduced to the bearing minimum level. This is due to be role of the product of Tsangaya schools who have been teaching the society to be God fearing person through activities of da ${ }^{6}$ wah and other teachings of Islam. ${ }^{42}$ As a result, the social vices were reduced, the rampant cases of divorce, intoxication among the youths were reduced within the ummah because of the presence of Islamic scholars who are the product of Tsangaya schools in the area. It has been stated in the interview as below:

Most of the youth in Potiskum are influenced by the teachings of the Tsangaya Scholars, and they have shunned most of the social vices such as drug addict, theft and thuggery, rather they embrace the good teachings of the Qur'an as preached and practiced by the Tsangaya teachers and students (PLA2). ${ }^{43}$

Besides that, the social life of Potiskum people especially marriages, divorce, superstition and charms have changed to that of Islamic teaching due to the persistence teaching and preaching by the Tsangaya teachers. These statements are supported by the interviews conducted where several respondents disclosed that:

\footnotetext{
${ }^{38}$ ALM5, Interview conducted with Almajiris Teacher at his residence in Arikime area Potiskum on the on 12th September 2020 at 3:11 3:58 p.m.

${ }^{39}$ PLA2, Online Interview with a person living with the Almajiri at his residence on the 3rd of October 2020 at 9:00.

${ }^{40}$ PLA3, Online Interview with a person living with the Almajiriat his shop on the 4th of October 2020 between 1:21-1:48 p.m.

${ }^{41}$ GOF2, Interview conducted with government official in his office on 14th May 2020 from 11:14 - 11:58 a.m.

${ }^{42}$ Poston, L. (1992), Islamic Dawah in the West: Muslim missionary activity and the dynamics of conversion to Islam, Oxford: Oxford University Press.

${ }^{43}$ PLA2, Online Interview with a person living with the Almajiri at his residence on the 3rd of October 2020 at 9:00.
} 
Sorceries and charms are among the social vices practices by the people of Potiskum, but as a result of the continuers effort of the Tsangaya school teachers, people were educated on the dangers involved in such acts. And most of the people in the area adhere to the teachings of Islam and shun away such barbaric and un-Islamic practices (PLA1). ${ }^{44}$

The marriage and divorce practices in Potiskum as more of tradition than the Islamic rite. Therefore, the teachers of the Tsangaya in the area has sanitize the system by enlighten and teaching the people the actual Islamic principles of marriage and divorce, presently the bad cultures in marriages and rampant divorces were at lowest level (PLA3). ${ }^{45}$

Hence, the above-mentioned positive effects of Tsangaya that has helped in mending the social life of the populace, the influence of the Tsangaya teachers and the Almajiri make the life of the people in the area inculcate good behavioural modes and adopt the Islamic teachings. The marital life of the Potiskum people has been improved, whereas most of the un-Islamic norms and cultures in marriages were abolished, divorce cases were reduced to the minimal as a result of the awareness and knowledge imparted by the Tsangaya school teachers and the Almajiri. Thus, it can be concluded that the people of Potiskum have benefited from the Tsangaya school and that the Tsangaya schools have positive effects on the Almajiri and the society in Potiskum, Yobe State.

\section{Conclusion}

The establishment of the Tsangaya System of Education in Potiskum and the presence of the Almajiri has contributed to the development of the educational system in the area especially in preserving the tradition of memorizing the glorious Qur'an among the society. The system has not only produced memorizers of the glorious Qur'an but also knowledgeable Almajiri and God-fearing people in Potiskum. Many Almajiri after graduated from Tsangaya schools became imams, scholars, judges, jurists, teachers and other well-meaning people in the area. The above-mentioned efforts will hopefully provide a better future for the Tsangaya schools. Therefore, the Tsangaya System of Education has not only give positive effects on Almajiri in terms of social, moral and spiritual situations but also the Potiskum and the other areas of Yobe State.

\section{References}

Abdulmalik, J., Omigbodun, O., Beida, O., \& Adedokun, B. (2009), "Psychoactive substance use among children in informal religious schools (Almajiris) in northern Nigeria," Mental Health, Religion and Culture, Vol. 12, No. 6, 527-542.

Adamu, A. U. (2010), "Islamic Education in African Countries - The Evolution of Non-Formal AlMuhajirun Education in Northern Nigeria," Discussion paper, Workshop of Islamic Education in African Countries, Istanbul, Republic of Turkey, 14th -18th June 2010.

Ademiluyi, I. A., \& Aluko-Arowolo, S. O. (2009), "Infrastructural distribution of healthcare services in Nigeria: An overview," Journal of Geography and Regional Planning, Vol. 2, No. 5, 104-110.

Ayuba, S. D. U. (2009), "Begging among Almajiri Qur'anic boarding school children of Almajici system of education in Sokoto metropolis," Unpublished M. Ed. Dissertation, Department of Education, UDU, Sokoto, 2009.

Babajo, H. H., Jamaluddin, Z., \& Hamid, S. A. (2017), "The Challenges of Tsangaya Quranic Schools in Contemporary Societies: A Study of Kano State Nigeria," Asian Journal of Multidisciplinary Studies, Vol. 5, No. 6, 243-250.

Babajo, H. H. (2018), "The Predicaments of Almajiris Children of the Street in Kano State Nigeria," Doctoral Thesis, Universiti Utara Malaysia.

\footnotetext{
${ }^{44}$ PLA1, Online Interview with a person living with the Almajiri at his residence on the 2nd of October 2020 at 4:00-5:30 p.m.

${ }^{45}$ PLA3, Online Interview with a person living with the Almajiri at his shop on the 4th of October 2020 between 1:21-1:48 p.m.
} 
Babajo, H. H. (2008), "Socio-economic Menace of Almajiri Syndrome: The way out," Journal of Religions Education, Languages and General Studies, Vol. 2, No. 1, 39-45.

Bambale, K. (2003), "The need for the reform of Almajiri System to Education for attainment of the Nigeria Vision 2020," Farfaru Journal of Multi-Disciplinary Studies (Special Conference Edition), Vol. 3, 519-524.

Bano, M., Antonisis, M. \& Ross, J. (2011), Islamiyya, Qur'anic and Tsangaya Education Institutions Census in Kano State (Final Draft Report). Kano, Nigeria: Education Sector Support Programme, Kano University.

Cachia, M., \& Millward, L. (2011), "The telephone medium and semi-structured interviews: a complementary fit," Qualitative Research in Organizations and Management: An International Journal, Vol. 6, No. 3, 265-277.

Churchill Jr, G. A., Ford, N. M., Hartley, S. W., \& Walker Jr, O. C. (1985), "The determinants of salesperson performance: A Meta-Analysis," Journal of Marketing Research, Vol. 22, No. 2, 103-118.

Eickelman, D. F (1978), "The Art of Memory: Islamic Education and Its Social Reproduction," Comparative Studies in Society and History, Vol. 20, No. 4, 485-516.

Isiaka, T. O. (2015), "A Pilot Study of the Challenges of Infusing Almajiri Educational System into the Universal Basic Educational Programme in Sokoto, Nigeria," Journal of Education and Practice, Vol. 6, No.16, 10-16.

Jones, N. A., Shaw, S., Ross, H., Witt, K., \& Pinner, B. (2016), "The study of human values in understanding and managing social-ecological systems," Ecology and Society, Vol. 21, No. 1, 15.

Mashema, B. L., \& Kawu, G. S. (2017), "The Integration of Traditional Islamic Education Schools with The Western Education Schools Model: A Case Study of Azare Tsangaya Model Boarding Primary School," International Journal of Innovative and Advanced Studies, Vol. 4, No. 7, 335-343.

Muhammad, R., Yusuf, A., \& Bello, M. B. (2013), "Teachers and Parents' Assessment of the Inclusive Education of the Almajiri and Education for All in Nigeria," Journal of Resourcefulness and Distinction, Vol. 6, No. 1, 1-11.

Odumosu, O., Odekunle, S., Bolarinwa, M., Taiwo, O., Ajala, A., Alonge, S. K., Akujobi, C. (2013), Manifestations of the Almajirai in Nigeria: Causes and Consequences, Nigerian Institute of Social and Economic Research.

Okonkwo, H. I., \& Ibrahim, M. (2014), "Contemporary Issues in Nomadic, Minority and Almajiri Education, Problems and prospects," Journal of Education and Practice, Vol. 5, No. 24, 19-27.

Poston, L. (1992), Islamic Dawah in the West: Muslim missionary activity and the dynamics of conversion to Islam, Oxford: Oxford University Press.

Punch, K. F. (2014), Introduction to Social Research: Quantitative and Qualitative Approaches, 3rd ed., London: Sage Publications.

Rasheed, M. I., Humayon, A. A., \& Awan, U. (2016), "Factors affecting teachers' motivation," International Journal of Educational Management, Vol. 30, No. 1, 101-114.

Shehu, S. (2006), "Improving Qur'anic (Tsangaya) education in Nigeria: Trends, issues, challenges and the way forward," Paper presented at the Workshop Organized by Borno State Agency for Mass Education, 2nd-5th May 2006.

Shuriye, A. O., \& Ibrahim, D. S. (2013), "Timbuktu Civilization and Its Significance in Islamic History," Mediterranean Journal of Social Sciences, Vol. 4, No. 11, 696-696. 
Tsangaya System of Education and its Positive Effects on Almajiri and Society in Potiskum, Yobe State Nigeria Sulaiman Salisu Muhammad (2021), "Six Years of Existence of Tsangaya Schools in Kaduna State (2010-2016): An Assessment," EAS Journal of Humanities and Cultural Studies, Vol. 3, No. 1, 1-4.

Tufeiru Fuseini \& Marguerite Daniel (2018), "Exploring the stressors and resources of Muslim child beggars in Dagbon of Northern Ghana in the context of child rights and existing realities," Cogent Social Sciences, Vol. 4, No. 1, 1542955.

Thapa, K., Ghatane, S., \& Rimal, S. P. (2009), "Health problems among the street children of Dharan municipality," Kathmandu University Medical Journal, Vol. 7, No. 27, 272-279.

Usman, T. (2018), "Qur'anic Schools in Northern Nigeria: Past Glory and Prevailing Challenges," in Dirasat Tarwabiyah, Vol. 7, 1-25.

Van Beek, W. E. (2012), "Intensive slave raiding in the colonial interstice: Hamman Yaji and the Mandara Mountains (North Cameroon and North-Eastern Nigeria)," The Journal of African History, Vol. 53, No. 3, 301-323.

Yahya A. (2018), "Tsangaya: The Traditional Islamic Education System in Hausaland," Jurnal Pendidikan Islam, Vol. 4, No. 1, 1-14.

Yusha'u, M., Tsafe, A., Babangida, S., \& Lawal, N. (2013), "Problems and prospects of integrated almajiri education in northern Nigeria," Scientific Journal of Pure and Applied Sciences, Vol. 2, No. 3, $125-134$.

Zakir, A., Abubakar, U., Lawal, U.S., Imrana, H., Habibu, I.T., Hassan, I.H., \& Harande, M.M. (2014), "The practice of Almajiri: Prospect and socio-medical challenges in Northern part of Nigeria," Journal of African Studies and Development, Vol. 6, No. 7, 128-131. 
Journal of Al-Tamaddun, Vol. 16 (2), 2021, 89-97 